\title{
Late/Middle/Early/Ichnocambrian: a communication-friendly nomenclature for the epochs of a quadripartite Cambrian Period
}

\author{
1 Department of Geoscience, University of Nevada, Las Vegas, Nevada 89154, USA.E-mail: steve.rowland@unlv.edu \\ 2 Current address: Exxon Mobil Upstream Research Co., P.O. Box 2189, Houston, Texas 77252, USA.E-mail: melissa.hicks@exxonmobil.com
}

\begin{abstract}
The International Subcommission on Cambrian Stratigraphy has voted to abandon the traditional tripartite subdivision of the Cambrian Period in favor of a quadripartite structure. Each of the four newly defined epochs will be assigned a name based on the location of the GSSP that defines the base of its basal stage. We do not question the biostratigraphic appropriateness of subdividing the Cambrian Period into four epochs rather than three, however we argue that it is unnecessary and unwise to completely abandon the widely used, easily remembered, relative-position-specific names Early, Middle, and Late Cambrian. We propose a simple epoch nomenclature, which retains the familiar names for the intervals of strata to which they have traditionally been applied, and adds just a single, new, easily-remembered name - Ichnocambrian - for the ichnofossil-defined, pre-trilobite-bearing portion of the Cambrian.
\end{abstract}

\section{Introduction}

Major developments are now occurring in the field of stratigraphy that will influence the way geologists communicate with one another and with non-geologists into the distant future. The most significant such development is the use of Global Stratotype Sections and Points (GSSPs) to define the bases of biostratigraphic stages (Gradstein et al., 2004). Historically, Cambrian stratigraphers have had more difficulty achieving international agreement on subdivision boundaries than have workers in most other Phanerozoic periods (Shergold and Cooper, 2004), and the emphasis on GSSPs has had a beneficial effect on the resolution of some long-standing problems in Cambrian stratigraphic nomenclature. The International Subcommission on Cambrian Stratigraphy (ISCS) is now moving quickly to establish a GSSP-based, biostratigraphic framework for the Cambrian Period. However, in their haste to establish this new framework, the ISCS is proposing a new epoch nomenclature that we consider to be unnecessarily awkward and a barrier to communication. The purpose of this paper is to propose an easily-remembered, communicationfriendly, epoch nomenclature for the reorganized, quadripartitie Cambrian Period, in lieu of a nomenclature based on arcane geographic names.

Since 1835, when Adam Sedgwick first named the Cambrian Period, it has been divided into three parts (Berry, 1987). But the boundaries of the three Cambrian epochs, particularly the EarlyMiddle Cambrian boundary, have not always been defined by ageequivalent horizons on different continents. Furthermore, the base of the Early Cambrian, which had traditionally been defined as the first occurrence of trilobites, was lowered by some biostratigraphers to incorporate small shelly fossils (Rozanov et al., 1981), and then lowered again to include complex trace fossils (Brasier et al., 1994; Landing, 1994). The result is that the Cambrian Period has come to represent a very long, evolutionarily dynamic, interval of time.

As advocated by Palmer (1998) and Geyer and Shergold (2000), the ISCS has voted to subdivide the Cambrian into four global epochs. Each epoch is to be named for the geographic locality or region that contains the GSSP that defines the base of its basal stage. The youngest of the anticipated four Cambrian epochs has recently been named the Furongian, which name replaces the traditional Late Cambrian (Peng et al., 2004). The name Furongian is derived from the Chinese word Furong, which means lotus. That name was chosen because the GSSP that defines the basal stage of the Furongian Epoch occurs within China's Hunan Province, the nickname of which is "the Lotus Province" (Peng et al., 2004). Thus a familiar, traditional name - Late Cambrian - that is easily remembered in any language is being replaced by an obscure name that will be difficult for nearly everyone to remember, especially when it is joined by equally obscure names for the other three Cambrian epochs. The older three Cambrian epochs have yet to be precisely defined and named.

There is no requirement to use geographic names for epoch names. Indeed, most Phanerozoic epochs are named early, middle, or late (Gradstein et al., 2004). The key problem with using such names in the Cambrian, of course, is that these descriptors work best when two or three intervals of time are being described. Because the ISCS has decided to subdivide the Cambrian into four epochs, it is understandable that they have also decided to abandon these traditional names and replace them with GSSP-based geographic names. The second youngest of the four epochs will essentially correspond to the traditional Middle Cambrian, while the Early Cambrian Epoch will be split in two. One of the two new epochs to be carved out of the Early Cambrian will correspond to the trilobite-bearing portion of the currently defined Early Cambrian, and the other will correspond to the pre-trilobite interval (Peng et al., 2004). Once the new quadripartite nomenclature is in place, it is the expectation and intention of the ISCS that the names Early Cambrian, Middle Cambrian, and Late Cambrian will disappear from the working parlance of geology.

\section{The importance of easily-remembered epoch names}

Recognizable epoch names are fundamental elements of a geologist's working vocabulary. Outside the community of Cambrian stratigraphers, GSSP-based epoch names will never be as recognizable as the traditional, relative-age-based names (Early, Middle, Late). The name Furongian, for example, will never be as widely recognized as the name Late Cambrian. Easily-remembered, widelyrecognized epoch names facilitate communication within the wider 
geological community, and such names are absolutely critical for facilitating communication between geologists and non-geologists concerning epoch-level time intervals. Due to the rapid diversification of life during the Cambrian Period, as well as the presence of spectacular Lagerstätten such as the Burgess Shale and the Chengjiang fauna, the Cambrian Period is of great interest to a wide spectrum of non-geologists and non-scientists. Of course, this interest is very important for the health of Cambrian studies, but it is also beneficial for paleontology and geology in general.

Scientists are often admonished for not communicating more effectively with policy makers and the general public. Cambrian paleontology is one of the few spectacular success stories in the sense that non-geologists have been successfully included in the excitement of Cambrian paleontological research. Many people scientists and non-scientists alike - have read the books about the Burgess Shale by Stephen Jay Gould (1989) and Simon Conway Morris (1998), and these readers have become intellectually engaged in the debate about the significance of the Burgess Shale fauna for human evolution. To such people it is significant that the Chengjiang fauna, for example, lived in the Early Cambrian, while the Burgess Shale fauna lived in Middle Cambrian. This type of interest is crucial if we are to successfully demonstrate to society that academic geology and paleontology are worthwhile scientific enterprises, and that museum collections are precious archives that are worth protecting and expanding. To encourage such interest and communication, we should strive to avoid erecting a framework of epoch names that is unintelligible outside of the small community of Cambrian stratigraphers.

\section{A proposed solution}

In the interest of facilitating rather than inhibiting communication, we propose a nomenclature that allows the retention of the familiar terms Early, Middle, and Late Cambrian. In accordance with ICS protocol, the traditional Middle Cambrian and Late Cambrian epochs are, for the first time, being internationally defined, which of course is a welcome development. These two newly named and newly defined intervals will, in most localities, closely conform to traditionally defined Middle and Late Cambrian strata. Thus, there is no good reason to stop referring to these intervals as Middle Cambrian and Late (or Upper) Cambrian, as they are labeled on countless published maps and stratigraphic columns. Geologists who have spent their careers working on these intervals will doubtless continue calling them by these traditional, relative-position-specific names, whether or not the ISCS sanctions such usage. While we acknowledge the linguistic awkwardness of using the term middle for the third epoch in a four-epoch period, we consider this minor awkwardness to be highly preferable to completely abandoning the term Middle Cambrian. Thus, we propose that the terms Late and Middle Cambrian be retained as officially recognized names.

The portion of the Cambrian that has stimulated the adoption of a quadripartite nomenclature is the Early Cambrian, which will be completely redefined. The lower, pre-trilobite-bearing portion will be separated from the trilobitic portion (Peng et al., 2004); each of these portions of the currently defined Early Cambrian will thus become a newly defined epoch.

Retaining relative-age-specific alternative names is clearly a problem for the soon-to-be-subdivided Early Cambrian; there is no linguistically graceful term for the second item in a four-item set. So, what simple, relative-age-specific name can be used for the trilobite-bearing, second epoch? Traditional usage dictates that it is the trilobite-bearing interval that must retain the name Early Cambrian. Only in recent years has the base of the Cambrian been lowered to include strata containing pre-trilobite, small shelly fossils and trace fossils. In the new quadripartite Cambrian Period, we propose that the term Early Cambrian be retained as the name of the second oldest of the four epochs, which contains olenellid and redlichiid trilobites (Figure 1).

\begin{tabular}{|c|c|c|c|}
\hline Period & $\begin{array}{c}\text { Gradstein et al. } \\
2004\end{array}$ & $\begin{array}{l}\text { ISCS } \\
\text { epochs }\end{array}$ & $\begin{array}{l}\text { Epoch nomenclature } \\
\text { proposed in this paper }\end{array}$ \\
\hline \multirow{4}{*}{ 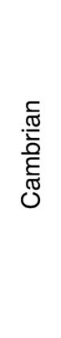 } & Furongian & Furongian & Late Cambrian \\
\hline & Middle Cambrian & $\begin{array}{c}\text { Cambrian } \\
\text { Epoch } 3 \\
\text { (undefined) }\end{array}$ & Middle Cambrian \\
\hline & \multirow{2}{*}{ Early Cambrian } & $\begin{array}{l}\text { Cambrian } \\
\text { Epoch } 2 \\
\text { (undefined) }\end{array}$ & Early Cambrian \\
\hline & & $\begin{array}{l}\text { Cambrian } \\
\text { Epoch } 1 \\
\text { (undefined) }\end{array}$ & Ichnocambrian \\
\hline
\end{tabular}

Figure 1 Comparison of three nomenclatures for the epochs of the Cambrian Period.

If, as we propose, the familiar names Early, Middle, and Late Cambrian are to be retained for the three youngest epochs of a fourpart Cambrian Period, obviously a fourth name will be required for the pre-trilobite-bearing basal Cambrian epoch. In lieu of a GSSPbased name for the oldest Cambrian epoch, we propose a new term Ichnocambrian. Derived from the paleontologically-familiar Greek root ichno, meaning "track" or "footprint," the Ichnocambrian Epoch can be easily remembered as the epoch whose base is defined by complex trace fossils, specifically Treptichnus pedum.

The use of this proposed epoch nomenclature will prevent arcane, insider jargon from inhibiting communication between Cambrian workers and other geologists, and between biostratigraphers and the non-scientists who pay their salaries. The test of the value of this proposed nomenclature will be its usage within the geologic community and beyond.

\section{References}

Berry, W.B.N., 1987, Growth of a prehistoric time scale: Palo Alto, Blackwell, $202 \mathrm{pp}$.

Brasier, M.D., Cowie, J.W., and Taylor, M., 1994, Decision on the Precambrian-Cambrian boundary stratotype: Episodes, v. 17, pp. 3-8.

Conway Morris, S., 1998, The crucible of creation: the Burgess Shale and the rise of animals: Oxford, Oxford University Press, $242 \mathrm{pp}$.

Geyer, G. and Shergold, J., 2000, The quest for internationally recognized divisions of Cambrian time: Episodes, v. 23, pp. 188-195.

Gould, S.J., 1989, Wonderful life: the Burgess Shale and the nature of history: New York, Norton, 347 pp.

Gradstein, F.M., Ogg, J.G., and Smith, A.G., 2004, eds., A geologic time scale 2004: Cambridge, Cambridge University Press, 589 pp.

Landing, E., 1994, Precambrian-Cambrian boundary global stratotype ratified and a new perspective on Cambrian time: Geology, v. 22, pp. 179182.

Palmer, A.R., 1998, A proposed nomenclature for stages and series for the Cambrian of Laurentia: Canadian Journal of Earth Sciences, v. 35, pp. 323-328.

Peng, S., Babcock, L.E., Robison, R.A., Lin, H., Rees, M.N., and Saltzman, M.R., 2004, Global standard stratotype-section and point (GSSP) of the Furongian Series and Paibian Stage (Cambrian): Lethaia, v. 37, pp. 365379.

Rozanov, A.Yu., Missarzhevsky, V.V., Volkova, N.A., Voronova, L.G., Krylov, I.N., Keller, B.M., Korolyuk, I.K., Lendzion, K., Michniak, R., Pykhova, N.G., and Siderov, A.D., 1969, The Tommotian Stage and the Cambrian Lower boundary problem: Trudy Geologicheskogo Instituta Akademiya Nauk SSSR, v. 206, Moscow [in Russian] [English translation, M.E. Raaben, (ed.), Amerind Publishing Co., New Delhi, India (1981), 359 pp.].

Shergold, J.H. and Cooper, R.A., 2004, The Cambrian Period, in Gradstein, F.M., Ogg, J.G., and Smith, A.G., eds., A geologic time scale 2004: Cambridge, Cambridge University Press, pp. 147-164. 


\section{Nomenclature of Cambrian epochs and series based on GSSPs - Comments on an alternative proposal by Rowland and Hicks}

1 State Key Laboratory on Palaeobiology and Stratigraphy, Nanjing Institute of Geology and Palaeontology, CAS, 39 East Beijing Road, Nanjing 210008, China. e-mail: scpeng@nigpas.ac.cn

2 Department of Geological Sciences, 125 South Oval Mall, The Ohio State University, Columbus, Ohio 43210, USA.e-mail: babcock.5@osu.edu

3 Institute für Palãontologie, Bayerische Julius-Maximilians-Universitãt, Pleicherwall 1, D-97070 Würzburg, Germany. e-mail:gerd.geyer@mail.uni-wuerzburg.de

4 Department of Earth Sciences, Uppsala University, Norbyvägen 22, SE-752.36 Uppsala, Sweden.e-mail:malgo.vidal@pal.uu.se

In this issue, Rowland \& Hicks advocate a nomenclature for the four epochs of the Cambrian Period that carries over the terms Early, Middle, and Late Cambrian from previous usage (but with new definitions) and introduces a non-geographically-based term, Ichnocambrian, for the earliest Cambrian epoch. The terms Lower/Early, Middle, and Late/Upper Cambrian are confusing because they connote the second, third, and fourth epochs/series of the period/system, and because each is defined in a way that is different from traditional definitions of those intervals. The use of these terms will ultimately lead to confusion between older concepts of Early, Middle, and Late Cambrian and newer, refined concepts of the epochs. The philosophy of the International Subcommission on Cambrian Stratigraphy for establishing a clear subdivision of the Cambrian on a global scale is unambiguous: stratigraphic terms previously in use lack global applicability and should not be adopted as chronostratigraphicl geochronologic units in the developing global stratigraphic chart of the Cambrian. Moreover, all series and stage names should be GSSP (stratotype section)-based.

For nearly three decades, the International Subcommission on Cambrian Stratigraphy (ISCS) has been working to develop internationally recognizable divisions of the Cambrian System/Period. One important step has been adoption of a chronostratigraphic/ geochronologic framework with four series/epochs and ten stages/ages (Peng \& Babcock, 2005; Babcock et al., 2005; Peng, 2006). This model has been approved by the Voting Members of the International Subcommission on Cambrian Stratigraphy (ISCS), and accepted by the International Commission on Stratigraphy (ICS; see International Stratigraphic Chart version 2006, posted on the official website of the ICS). In accordance with ICS standards, chronostratigraphic terms (series and stages) for the new Cambrian timescale shall be based on Global Standard Stratotype-sections and Points (GSSPs). Because of difficulties in applying older concepts of Cambrian subdivisions on a global scale (Shergold and Geyer, 2000), the ISCS has adopted the policy of introducing new chronostratigraphic/geochronologic terms based on horizons that have utility for correlation on an intercontinental scale (Peng et al., 2004; Babcock et al., 2005). To avoid confusion with terms applied previ- ously, and often having only regional applicability, the ISCS has also adopted the policy of introducing new names for chronostratigraphic subdivisions based on the geographic locations of the GSSPs that define the units. In the following discussion, only chronostratigraphic terms will be used.

Rowland \& Hicks (this issue) have proposed a nomenclature for the Cambrian that is based on the relative stratigraphic positions of series rather than GSSPs and stratotype sections. In their nomenclatural scheme, the Cambrian System has been subdivided into four series following recent ISCS recommendations (Peng \& Babcock, 2005; Babcock et al., 2005; Peng, 2006) but carries over from previous usage the Lower, Middle, and Upper series for the second, third, and fourth series, respectively. The first series of the Cambrian in their nomenclatural scheme is termed the Ichnocambrian. In our opinion, this proposal will only increase confusion over terminology rather than diminish it. The newly redefined Lower, Middle, and Upper series do not correspond to most definitions of series using those terms. Furthermore, the disconnect between terms deriving from earlier tripartite divisions of the Cambrian and the accepted quadripartite subdivision will lead to linguistic awkwardness.

To avoid confusion in applying the concepts of Cambrian chronostratigraphic units globally, it is necessary to produce a new set of unambiguous names for chronostratigraphic subdivisions. Previously used series and stage names should not be used in the developing Cambrian chronostratigraphic scheme because of possible ambiguity over earlier and current (future) meanings of those names. Also, Cambrian series and stage names should be GSSP (stratotype section)-based.

So far, only one Cambrian series name and one stage name have been ratified by the ICS. Following procedures described in the International Stratigraphical Guide (Salvador, 1994), the name of the uppermost Cambrian series (Furongian) and its basal stage (Paibian) have been named for geographic names in the vicinity of the GSSP that defines the conterminant base of these two units. The geographic locality-based name Furongian is parallel to the name Cambrian, which derives from a Latin variant of the Celtic name for Wales (Cumbria; Cowie et al., 1972). For uniformity, each of the remaining series and stage names for the Cambrian will be derived from geographic localities associated with the GSSPs that define their bases.

The ISCS welcomes and appreciates Rowland \& Hicks's constructive suggestion about using a communication-friendly nomenclatural scheme for Cambrian subdivisions, but we view their specific scheme as inappropriate for the following four reasons:

1. Rowland \& Hicks place undue emphasis on the ability to easily remember series names. Traditional position-based nomenclatures of Cambrian subdivisions may be appealing to many geologists and non-scientists. However, one inevitable consequence of this nomenclatural arrangement is confusion over the concepts of the tra- 
ditional Lower, Middle, and Upper Cambrian series and the redefined series, as both arrangements share the same names.

For more than 150 years there has been inconsistent application of the terms Lower, Middle, and Upper for Cambrian series. In 1835, Adam Sedgwick named the Cambrian System from strata in North Wales, and subdivided the system into Lower, Middle and Upper parts. Later, the uppermost part of his Lower Cambrian (the "Arenig Slates" and the "Tremadoc Slates") and his Middle and Upper Cambrian were excluded from Cambrian. As usually restricted, the Cambrian of Wales comprises only part of Sedgwick's (1852) Lower Cambrian (Cowie et al., 1972; Shergold and Copper, 2004).

A tripartite subdivision of the Cambrian has commonly been applied around the world, and usually the three divisions are called Lower, Middle, and Upper Cambrian (although they differ entirely in concept from Sedgwick's tripartite subdivision of the system). Unfortunately the traditional Lower-Middle and Middle-Upper Cambrian series boundaries have usually been placed at stratigraphic levels that are difficult to identify and correlate on a global scale. As a result, the boundaries, as recognized in different paleogeograpghic regions (and sometimes even neighboring regions of the same paleocontinent), are at different chronostratigraphic levels (Geyer, 1990, 1998, 2005; Geyer and Shergold, 2000; Peng et al., 2004). Moreover, addition of considerable stratigraphic thickness to the Cambrian below its traditional base (Landing, 1994), has led to inconsistent use of the term Lower Cambrian in all paleogeographic regions. Geologic maps published prior to 1994 employ a much different concept of Lower Cambrian than do those published since that time. Currently, geologists using a tripartite division of the Cambrian for field work in Baltica, Siberia, Australia, and North America are all working under different sets of criteria if they are applying Lower, Middle, and Upper Cambrian series names. In the view of the ISCS, adoption of traditional series names as global chronostratigraphic names would merely continue and exacerbate the current state of imprecision in, and inconsistent definition of, Cambrian series.

The Furongian Series and the as-yet-unnamed Series 3 in the new Cambrian chronostratigraphic framework do not "closely conform to the traditionally defined Middle and Upper Cambrian" as discussed by Rowland \& Hicks, but represent different stratigraphic intervals. That is to say, the Furongian Series does not replace any of the traditional definitions of Upper Cambrian, but is an interval defined in a new way. Likewise Series 3 will not replace the Middle Cambrian, but will be a new stratigraphic unit. The base of the Furongian is defined by a GSSP (Peng et al., 2004), and its position, at the first appearance datum (FAD) of the cosmopolitan trilobite Glyptagnostus reticulatus, is well above traditional bases of the Upper Cambrian. The position commonly used for the base of the Upper Cambrian in Baltica, and variably applied elsewhere (especially Laurentia) was marked by a local abundance of the trilobite Agnostus pisiformis, which has a limited distribution globally (Peng and Robison, 2000). The top of the Furongian Series, which is automatically defined by the base of the overlying Tremadocian Series (Ordovician System) at the FAD of the conodont Iapetognathus fluctivagus (Cooper et al., 2001), is stratigraphically lower than the top of any traditional definition of the Upper Cambrian. Almost certainly, the base of Cambrian Series 3 will be at a position that differs from most, if not all, traditional positions of the base of the Middle Cambrian (Geyer, 2005).

Not only do Cambrian Series 3 and the Furongian Series differ in concept and definition from traditional interpretations of Middle and Upper Cambrian, but Cambrian Series 1 and 2, once defined, are also expected to differ markedly from traditional concepts of the Lower Cambrian. Series 2 is an interval that only occupies about half of the upper part of the "Lower Cambrian" (Landing, 1991; Shergold and Cooper, 2004; Gradstein et al., 2004; Figure 1).

2. If the nomenclature proposed by Rowland \& Hicks (this issue, Figure 1) is accepted, their Lower, Middle and Upper Cambrian, which occur successively above another named series of the Cambrian, will automatically lose their meaning as positional indicators. They will also be different in meaning from the homonymous (but not synonymous) terms used in earlier tripartite subdivisions of

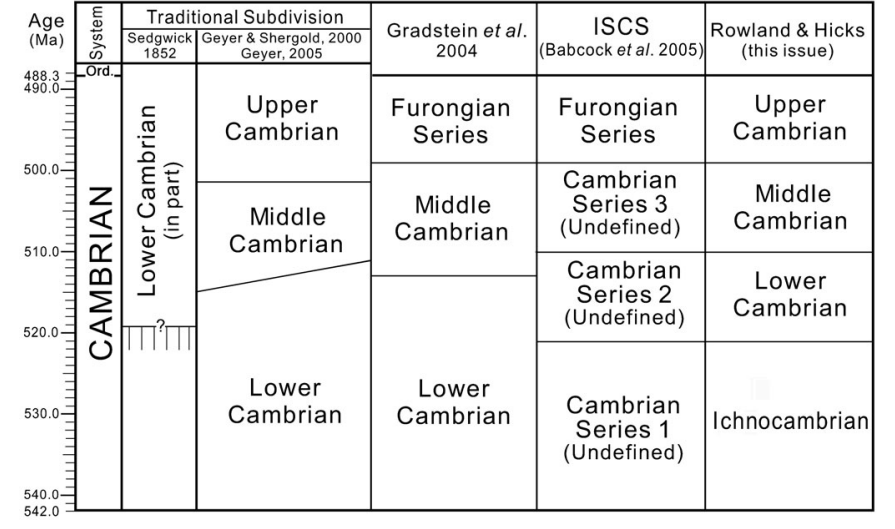

Figure 1 Correlations of traditional and recently proposed chronostratigraphic subdivisions for the Cambrian System. Ages for the bases of Cambrian and Ordovician systems are from ICS (2006); ages for other series bases in ISCS subdivision are tentatively estimated as $521 \pm 2.0 \mathrm{Ma}$ (Series 2), 510 $\pm 1.0 \mathrm{Ma}$ (Series 3), and 499 $\pm 2.0 \mathrm{Ma}$ (Furongian Series).

the Cambrian. Their "relative-position-specific" series in the quadripartite Cambrian System will almost certainly be misunderstood because their names do not correctly indicate the positions of the series in sequence. Use of "Lower Cambrian" for the interval that represents the second quarter, rather than the first quarter, of Cambrian stratigraphy is linguistically awkward and confounding.

3. As recommended by the ISC, "a new stage/series name should preferably be derived from a geological feature in the vicinity of its type section and type area" (Salvador, 1994). The ISCS concurs with the ICS in this recommendation and expects that all Cambrian chronostratigraphic names will be GSSP- and stratotypelocation-based. Therefore, a non-GSSP-based name like Ichnocambrian, as proposed by Rowland \& Hicks for the basal Cambrian series, is unacceptable. The "Ichnocambrian Series", whose base would be defined by complex trace fossils, can be easily misunderstood as a Cambrian series dominated by ichnofossils. In actuality, the basal Cambrian series will, by necessity, be characterized mostly by small shelly fossils.

4. A geographically-based nomenclature for systems, series, and stages is not an invention of the ISCS, and names based on geographic localities do not constitute "insider jargon". The practice of using geographically-based names for systems has been successfully applied to the Cambrian, Ordovician, Silurian, Devonian, Permian, and Jurassic; for series, it has been applied to the Silurian, Carboniferous and Permian systems; and for stages, it has been applied to almost the entire Phanerozoic. Instituting a parallel structure to the nomenclature for Cambrian series and stages should not result in unnecessary awkwardness of language, nor should it inhibit communication; it is just a new set of names (with new definitions). The names will reflect the geographic locations of the sections best illustrating the correlation criteria used to define the bases of the chronostratigraphic units.

In summary, it is our opinion that new, precisely defined chronostratigraphic names are a necessity for providing a misunderstanding-free, common language for geologists, biologists, and nonscientists. The three upper series of the Cambrian are, or soon will be, newly defined series that differ substantially in concept, scope, and method of correlation from historical definitions of the Lower, Middle, and Upper Cambrian. Replacing the names of the newly defined chronostratigraphic units with the names Lower, Middle, and Upper Cambrian will certainly lead to confusion and ambiguity.

In the near future, about 20 new chronostratigraphic names will be added to the International Stratigraphic Chart, of which 12 will be names for Cambrian series and stages. The names may seem unfamiliar at first, but precise definition of chronostratigraphic intervals and precise communication among scientists and non-scientists is the goal of both the ICS and the ISCS. We feel that this objective 
outweighs the imprecision and miscommunication that is likely to result from using redefined, but familiar-sounding, names. Already it is clear that this work is paying off: the term "Furongian Series", which was recently ratified (Peng et al., 2004) has been smoothly applied in publications by colleagues representing disparate areas of the world. It is our expectation that the geographically-based names to be ratified in the near future will also be easy to apply globally.

\section{References}

Babcock, L.E., Peng Shanchi, Geyer, G., and Shergold, J.H., 2005. Changing perspectives on Cambrian chronostratigraphy and progress toward subdivision of the Cambrian System. Geoscience Journal, v. 9, pp. 101-106.

Cowie, J.W., Rushton, A.W.A., and Stubblefield, C.J., 1972. A correlation of Cambrian rocks in the British Isles. Scottish Academic Press, Belfast, 42 pp.

Cooper, R.A., Nowlan, G.S., and Williams, S.H., 2001. Global Stratotype Section and Point for base of the Ordovician System. Episodes, v. 24, pp. 19-28.

Geyer, G., 1990. Correlation along the Lower/Middle Cambrian boundary a puzzling story with an elusory end? in Repina, L.N. and Zhuravlev, A.Y., eds, Third International Symposium on the Cambrian System, 1-8 August 1990, Novosibirsk, USSR, Abstracts, Novosibirsk, pp.100-102.

Geyer, G., 1998. International, trilobite-based correlation of the Moroccan early Middle Cambrian. Canadian Journal of Earth Sciences, v. 35, pp. 374-401.

Geyer, G., 2005. The base of revised Middle Cambrian: are suitable concepts for a series boundary in reach? Geoscience Journal, v. 9, pp. 81-99.

Geyer, G. and Shergold, J., 2000. The quest for internationally recognized divisions of Cambrian time. Episodes, v. 23, pp. 188-195.
Gradstein, F.M., Ogg, J.G., Smith, A.G., Bleeker, W., and Lourens, L.J., 2004. A new geologic time scale with special reference to Precambrian and Neogene. Episodes, v. 27, pp. 83-100.

International Commission on Stratigraphy, 2006. International stratigraphic chart. http://www.stratigraphy.org/cheu.pdf.

Landing, E., 1991. Upper Precambrian through Lower Cambrian of Cape Breton Island: faunas, paleoenvironments, and stratigraphic revision. Journal of Paleontology, v. 65, pp. 570-595.

Landing, E., 1994. Precambrian-Cambrian boundary global stratotype ratified and a new perspective of Cambrian time. Geology, v. 22, pp. 179-182.

Peng Shanchi, 2006. A new global framework with four series for Cambrian System. Journal of Stratigraphy, v. 30, pp. 147-148.

Peng Shanchi and Babcock, L.E., 2005. Newly proposed global chronostratigraphic subdivision of Cambrian System. Journal of Stratigraphy, v. 29, pp. 92, 93, 96 .

Peng Shanchi and Robison, R.A., 2000. Agnostoid biostratigraphy across the Middle-Upper Cambrian boundary in China. Paleontological Society Memoir 53, (Supplement to Journal Paleontology, 74), 104 pp.

Peng Shanchi, Babcock, L.E., Robison, R.A., Lin, Huanling, Rees, M.N., and Saltzman, M.R., 2004. Global standard stratotype-section and point (GSSP) of the Furongian Series and Paibian Stage (Cambrian). Lethaia, v. 37, pp. 365-379.

Rowland S.M. and Hicks, M., 2006. Late/Middle/Early/Ichnocambrian: a communication-friendly nomenclature for the epochs of a quadripartite Cambrian Period. Episodes (this issue)

Salvador, A., ed., 1994. International stratigraphical guide $\tilde{n}$ a guide to stratigraphic classification, terminology and procedure, 2nd edition. IUGS and the Geological Society of America, 214 pp.

Sedgwick, A., 1852. On the classification and nomenclature of the Lower Palaeozoic rocks of England and Wales. Quarterly Journal of the Geological Society of London, v. 9, pp. 136-168.

Shergold, J.H. and Cooper, R.A., 2004. The Cambrian Period. in Gradstein, F.M., Ogg, J.G., and Smith, A.G., eds., A geologic time scale 2004. Cambridge University Press, Cambridge. pp. 147-164

\section{Episodes is your window to the world. Subscribe today!}

\section{Episodes}

\section{Subscription Order}

Name (please print)

Address

City State/Prov.

Country Zip/Postal Code

Please begin my subscription:

$\begin{array}{llll}\text { March } & \text { June } & \text { Sept. } & \text { Dec. } \\ \text { Year } & \text { Year } & \text { Year } & \text { Year }\end{array}$

To start your subscription, fill in this form and mail to:

\section{Episodes}

P.O. Box 823

26 Baiwanzhuang Rd.,

Beijing 100037, China

Tel: +86-10-6832 0827; +86-10-68329084

Fax: +86-10-6832 8928

E-mail:episodes88@yahoo.com
Payment may be made by:

- Checks (US \$ only) made payable to Episodes

- $\square$ Diners $\square$ JCB $\square$ Visa $\square$ American Express $\square$ Mastercard

Please quote account number, expiry date and signature.

Account\#

Expiry date

Signature

Annual subscription rates: US\$24 